\title{
Physico-chemical Evaluation of Rosmarinus officinalis L. Essential Oils
}

\author{
Ana Cristina Atti-Santos ${ }^{1,2 *}$, Marcelo Rossato ${ }^{1,3}$, Gabriel Fernandes Pauletti ${ }^{1}$, Luciana \\ Duarte Rota ${ }^{1}$, Juarez Ciro Rech ${ }^{1}$, Marcia Regina Pansera ${ }^{1}$, Fabiana Agostini ${ }^{1}$, Luciana Atti \\ Serafini $^{1,2}$ and Patrick Moyna ${ }^{4}$ \\ ${ }^{1}$ Instituto de Biotecnologia; ${ }^{2}$ Departamento de Física e Química; ${ }^{3}$ Departamento de Ciências Exatas e da \\ Natureza; Universidade de Caxias do Sul; Rua Francisco Getúlio Vargas, 1130; 95001-970; Caxias do Sul - RS - \\ Brasil. ${ }^{4}$ Cátedra de Ciência y Tecnologia de Alimentos; Facultad de Química; UR; 11800; Montevideo - Uruguay
}

\begin{abstract}
Nineteen samples of Rosmarinus officinalis were extracted by steam distillation in a pilot plant and evaluated in terms of chemical compositions and physico-chemical characteristics. The volatile oil yields ranged from $0.37 \%$ (1999 harvest) to $0.49 \%$ (1998 harvest). Twenty components were identified in the oils. The major components were alpha-pinene (40.55 to 45.10\%), 1,8-cineole (17.40 to 19.35\%), camphene (4.73 to 6.06\%) and verbenone (2.32 to $3.86 \%)$. The physico-chemical parameters averaged $0.8887 \mathrm{~g} / \mathrm{cm}^{3}$ for specific gravity, 1.4689 for refractive index, and $+11.82^{\circ}$ for optical rotation, and there were no significant variations in either the chemical or physicochemical data in the different years.
\end{abstract}

Key words: Rosmarinus officinalis, rosemary, essential oil composition, alpha-pinene, 1,8-cineole, physicochemical parameters

\section{INTRODUCTION}

Rosmarinus officinalis L. (Lamiaceae) is a small evergreen which grows wild in most Mediterranean countries (Hèthelvi et al., 1987), reaching a height of $1.5 \mathrm{~m}$. The main producers are Italy, Dalmatia, Spain, Greece, Turkey, Egypt, France, Portugal and North Africa (Svoboda and Deans, 1992). The botany of rosemary is rather complex, as there are several species within the Genus Rosmarinus, with a range of varieties and forms (Ghenther, 1985). Essential oils of $R$. officinalis, known as rosemary oils, are obtained by steam distillation of the fresh leaves and twigs, and the yields range from 0.5 to $1.0 \%$ (Tewari and Virmani, 1987). It is an almost colorless to pale yellow liquid with a characteristic, refreshing and pleasant odor. Major constituents described for the oil are $\alpha$-pinene, 1,8-cineole and camphor (Bauer et al., 1997).

Significant variations in the chemical composition of oil have been reported with relation to the geographic origin (Tuker and Maciarello, 1986; Tewari and Virmani, 1987; Mizrahi et al., 1991; Svoboda and Deans, 1992; Chalchat et al., 1993; Lawrence, 1995; Rao et al., 1997; Dellacassa et al., 1999). Time of harvest, condition of the twigs and leaves, distillation equipment and management have also been reported to have an important role in the overall quality of the oil (Tewari and Virmani, 1987).

\footnotetext{
* Author for correspondence
} 
In this paper we report the chemical composition and the associated physico-chemical properties of rosemary essential oils extracted on a pilot scale installation during the years 1998, 1999 and 2000, with the aim of establishing the quality and chemical stability of the essential oils produced in the Southern region of Brazil.

\section{MATERIAL AND METHODS}

\section{Plant Material}

Rosmarinus officinalis was harvested in Campestre da Serra (Rio Grande do Sul State) during the years 1998, 1999 and 2000. The plants were identified by the Drs. R. Wasun and M. Rossato (Herbarium of the Museu de Ciências Naturais da Universidade de Caxias do Sul), and voucher specimens were deposited under catalogue number 8389.

\section{Essential Oil Extraction}

Essential oils were distilled from the aerial parts of the plants in the pilot plant. The amount of fresh plant used varied from 60 to $310 \mathrm{Kg}$. A total of 6 extractions were completed in 1998, 7 in 1999 and 6 in 2000. The plant material was loaded in the still and disposed in layers to allow suitable distribution of the steam. The lid was hermetically closed and the process of distillation began with the injection of steam in the bottom of the still. The pressure employed during distillation was $3.6 \mathrm{Kgf} / \mathrm{cm}^{2}$, and the duration was $90 \mathrm{~min}$. Steam and essential oils were condensed and collected in the florentine flask. The oils were dried over sodium sulphate and stored in clean brown glass bottles, and kept in a controlled temperature chamber at $20^{\circ} \mathrm{C}$, until the time of their analyses.

\section{Physico-chemical analyses}

Specific gravity $(S G)$ was measured with an Anton Paar Modelo DMA23 ${ }_{\mathrm{N}}$ densimeter. Viscosity (V) was measured with a Brookfield DV-II Viscosimeter, at $20^{\circ} \mathrm{C}$. Optical Rotation $(O R)$ was measured with a CETI Polaris polarimeter. Solutions of $40 \mathrm{~g} / \mathrm{L}$ of the essential oil samples in analytical grade chloroform (Merck). The readings were made with $1 \mathrm{dm}$ tubes at $20^{\circ} \mathrm{C}$. Refractive index (RI) was measured with a CETI Quartz refractometer, at $20^{\circ} \mathrm{C}$.
Solubility in ethanol (SE): The tests were made by complete solubilization of $1 \mathrm{~mL}$ of essential oil in $85 \%$ dilute ethanol, at $20^{\circ} \mathrm{C}$.

Residue on evaporation (RE): The evaporation residue was measured by adding $3 \mathrm{~g}$ of essential oil sample in a Petry dish, evaporating in a boiling water bath, cooling in a desiccator, until two successive weights gave a difference of less than $0,1 \%$.

Boiling point (BP): $0.5 \mathrm{~mL}$ of sample was used to fill a wide bore capillary tube with an inversed thin capillary inside. This set up was fixed to the stem of a thermometer. The thermometer was then partially immersed in an glycerol bath, at a temperature dependent on the sample of essential oil used. The continuous and rapid flow of bubbles in the wide capillary was taken as boiling point.

\section{Chemical Identification}

Gas chromatographic (GC) analysis were performed with a Hewlett Packard 6890 Series equipped with a HP-Chemstation data processor, fitted with a HP-Innowax bonded phase capillary column $(30 \mathrm{~m} \times 0.32 \mathrm{~mm}$ i.d., $0.50 \mu \mathrm{m}$ film thickness, Hewlett Packard, Palo Alto, USA); column temperature, $40^{\circ} \mathrm{C}(8 \mathrm{~min})$ to $180^{\circ} \mathrm{C}$ at $3^{\circ} \mathrm{C} / \mathrm{min}, 180^{\circ}-230^{\circ} \mathrm{C}$ at $20^{\circ} \mathrm{C} / \mathrm{min}, 230^{\circ} \mathrm{C}(20$ $\mathrm{min}$ ); injector temperature $250^{\circ} \mathrm{C}$; detector temperature $250^{\circ} \mathrm{C}$; split ratio 1:50; carrier gas $\mathrm{H}_{2}$ (34KPa). Volume injected $1 \mu \mathrm{L}$ diluted in hexane (1:10). The GC/MS analysis were performed in a HP 6890 GC using a mass selective detector Hewlett Packard 6890/MSD5973, equipped with HP Chemstation software and Wiley 275 spectra data. A fused silica capillary column HP-Innowax $(30 \mathrm{~m} \times 0.25 \mathrm{~mm}), 0.25 \mu \mathrm{m}$ film thickness (Hewlett Packard, Palo Alto, USA) was used. The temperature program was the same used in the gas chromatography (GC) analysis: interface $280^{\circ} \mathrm{C}$; split ratio 1:100; carrier gas $\mathrm{He}(56 \mathrm{KPa})$; flow rate: $1.0 \mathrm{~mL} / \mathrm{min}$; ionization energy $70 \mathrm{eV}$; mass range 40-350; volume injected $0.4 \mu \mathrm{L}$ diluted in hexane (1:10). Identification of the individual components was based on comparison of their GC retention indices (RI) on polar columns and comparison with mass spectra of components by GC/MS.

The data obtained for the chemical and physicochemical parameters were submitted to a variance analysis (ANOVA) and a test of mean comparison 
(Tukey 5\%) using the computer program SPSS 10.0. 6 repetitions each were used for the samples of 1998 and 2000, and 7 for 1999.

\section{RESULTS AND DISCUSSION}

The essential oil of $R$. officinalis $\mathrm{L}$. gave an average yield of $0.49 \% \mathrm{v} / \mathrm{w}$ in $1998,0.37 \% \mathrm{v} / \mathrm{w}$ in 1999 and $0.45 \%$ in 2000 . The components, the percentage of each constituent and their retention indexes were summarized in Table 1. To simplify the presentation the mean for each year are used. The components are arranged in order to GC elution on the Innowax columns. The main compounds were $\alpha$-pinene ( 40.55 to $45.10 \%), 1,8$ cineole (17.40 to $19.35 \%$ ), camphene (4.73 to $6.06 \%$ ), verbenone (2.32 to $3.86 \%$ ) and borneol (2.24 to $3.10 \%)$. Other components were found in less quantity $(<2 \%)$. The main components in this chemotype were different from those quoted by Price and Price (1999), identified as QT pinenecineole.

Table 1- Percentual chemical composition (average of years) of Brazilian rosemary essential oils

\begin{tabular}{l|c|c|c|c}
\hline \multicolumn{1}{c}{ Compounds } & $\mathbf{1 9 9 8}$ & $\mathbf{1 9 9 9}$ & $\mathbf{2 0 0 0}$ & Retention Indices \\
\hline$\alpha$-pinene & 40.55 & 45.10 & 41.63 & 1010 \\
camphene & 5.17 & 6.06 & 4.73 & 1032 \\
$\beta$-pinene & 2.70 & 2.86 & 2.40 & 1062 \\
sabinene & 0.74 & 0.67 & 0.84 & 1079 \\
myrcene & 1.39 & 1.59 & 1.71 & 1141 \\
$\alpha$-phelandrene & 0.50 & 0.43 & 0.45 & 1155 \\
limonene & 3.41 & 3.81 & 3.33 & 1188 \\
1,8-cineole & 17.40 & 17.59 & 19.35 & 1200 \\
$\gamma$-terpinene & 1.11 & 0.75 & 0.82 & 1243 \\
para-cymene & 0.99 & 1.56 & 1.23 & 1267 \\
$\alpha$-terpinolene & 0.92 & 0.69 & 0.68 & 1278 \\
chrysanthenone & 0.65 & 0.51 & 0.53 & 1509 \\
camphor & 2.13 & 1.63 & 2.42 & 1516 \\
linalool & 2.02 & 1.71 & 2.16 & 1528 \\
bornyl acetate & 1.39 & 1.02 & 0.80 & 1538 \\
$\beta$-caryophyllene & 2.80 & 2.11 & 2.16 & 1543 \\
terpinen-4-ol & 0.75 & 0.51 & 0.70 & 1551 \\
verbenone & 3.83 & 2.32 & 3.86 & 1595 \\
borneol & 2.97 & 2.24 & 3.10 & 1750 \\
geraniol & 2.68 & 2.07 & 2.61 & \\
Non oxygenated & 60.28 & 65.63 & 59.98 & \\
Oxygenated & 33.82 & 29.60 & 35.53 & \\
Total & 94.10 & 95.23 & 95.51 & \\
\hline
\end{tabular}

The statistical treatment of chemical data (Table 2) showed that the differences in terms of concentration of the main constituents were nonsignificant. There was no influence of the year of harvest in the chemical composition or other characteristics of the oils. Compared with other rosemary oils, Brazilian oils were more similar to those of French origin due to their 1,8-cineole and camphor contents (Tewari and Virmani, 1987; Chalchat et al., 1993; Lawrence, 1995). There was also similarity between Brazilian oils and oils of North American cultivars (Tuker and Maciarello, 1986).
In Table 3, the mean values for some physicochemical properties are shown. Their statistical treatment (Table 4) shows small variations among the samples, which were non-significant, with the exception of the Residue on Evaporation. Those for 2000 were lower than those for 1998 and 1999. Taking the data for these properties, Brazilian rosemary oils showed a mean refractive index of 1.4689 , an average optical rotation of $+11.82^{\circ}$, and an average specific gravity of $0.8887 \mathrm{~g} / \mathrm{cm}^{3}$. In relation to samples from other world zones, Brazilian oils were closer to those from France and 
Italy (Tewari and Virmani, 1987; Chalchat et al.., 1993; Lawrence, 1995).

These results are an initial contribution to the establishment of average values of chemical and physico-chemical parameters for a regional product of interest to industry. The stability of its composition and characteristics over several years is also relevant for its commercial utilization, as it is the basis of a consistent product.

Table 2 - Variance analysis (ANOVA), yearly mean values and general area mean ( $\mathrm{pA} * \mathrm{~S})$ of the main chemical constituents in rosemary oils $-{ }^{n s}$ Non significant

\begin{tabular}{cc|ccc|ccc|ccc|c|c}
\hline & $\boldsymbol{\alpha}$-pinene & canfene & $\boldsymbol{\beta}$-pinene & limonene & 1,8-cineole & camphor & linalool & verbenone & borneol & geraniol \\
\hline $\mathrm{F}$ & $0,620^{\mathrm{ns}}$ & $2,51^{\mathrm{ns}}$ & $1,20^{\mathrm{ns}}$ & $1,18^{\mathrm{ns}}$ & $0,519^{\mathrm{ns}}$ & $2,041^{\mathrm{ns}}$ & $1,566^{\mathrm{ns}}$ & $2,68^{\mathrm{ns}}$ & $2,19^{\mathrm{ns}}$ & $2,32^{\mathrm{ns}}$ \\
1998 & 6116,26 & 786,46 & 404,03 & 513,80 & 2603,84 & 320,02 & 300,14 & 565,68 & 441,07 & 399,60 \\
1999 & 6641,58 & 891,11 & 417,85 & 561,25 & 2583,01 & 240,39 & 250,97 & 341,90 & 327,95 & 301,50 \\
2000 & 6023,41 & 673,75 & 343,92 & 483,58 & 2876,90 & 363,77 & 325,06 & 598,02 & 469,33 & 386,68 \\
Average & 6280,48 & 789,42 & 390,14 & 521,73 & 2682,40 & 304,50 & 289,89 & 493,45 & 408,32 & 359,37 \\
\hline
\end{tabular}

Table 3 - Physico-chemical properties (average of years) of Rosemary oils from Brazil

\begin{tabular}{lccc}
\hline & \multicolumn{3}{c}{ Harvest year } \\
\cline { 2 - 4 } & $\mathbf{1 9 9 8}$ & $\mathbf{1 9 9 9}$ & $\mathbf{2 0 0 0}$ \\
\hline Refractive index & 1.4697 & 1.4682 & 1.4689 \\
Optical rotation $\left({ }^{\circ}\right)$ & +11.75 & +12.13 & +11.58 \\
Solubility in $85^{\circ}$ ethanol $(\mathrm{v}: \mathrm{v})$ & 0.85 & 0.82 & 0.74 \\
Viscosity $(\mathrm{cP})$ & 4379 & 4080 & 4756 \\
Specific gravity $\left(\mathrm{g} / \mathrm{cm}^{3}\right)$ & 0.8891 & 0.8858 & 0.8911 \\
Evaporation index $(\%)$ & 0.78 & 0.60 & 0.13 \\
Boiling point $\left({ }^{\circ} \mathrm{C}\right)$ & 122 & 118 & 130 \\
\hline
\end{tabular}

Table 4 - Variance analysis (ANOVA), mean comparison test (Tukey 5\%), mean annual values and general average of the physico-chemical parameters for Brazilian rosemary essential oils

\begin{tabular}{cccccccccc}
\hline & $\mathbf{R I}$ & $\mathbf{O R}\left({ }^{\circ}\right)$ & $\mathbf{S E}(\mathbf{m L})$ & $\mathbf{V}(\mathbf{c P})$ & $\mathbf{S G ~}\left(\mathbf{g} / \mathbf{c m}^{\mathbf{3}}\right)$ & $\mathbf{R E}(\boldsymbol{\%})$ & $\mathbf{B P}\left({ }^{\circ} \mathbf{C}\right)$ \\
\hline $\mathrm{F}$ & $1,316^{\mathrm{ns}}$ & $1,249^{\mathrm{ns}}$ & $0,646^{\mathrm{ns}}$ & $1,765 \mathrm{~ns}$ & $3,493 \mathrm{~ns}$ & $16,856 *$ & $1,158^{*} \mathrm{~ns}$ \\
1998 & 1,4696 & 10,0817 & 0,8500 & 4379,00 & 0,88911 & $0,7850 \mathrm{a}$ & 122 \\
1999 & 1,4638 & 12,1286 & 0,8286 & 4080,42 & 0,88580 & $0,6042 \mathrm{a}$ & 118 \\
2000 & 1,4689 & 11,5814 & 0,7429 & 4585,66 & 0,89112 & $0,3457 \mathrm{~b}$ & 130 \\
Mean & 1,4673 & 11,3230 & 0,8050 & 4334,26 & 0,88866 & 0,5680 & 123,3 \\
\hline
\end{tabular}

ns non significant; * significant at 5\%. Mean values followed by the same letters do not differ by Tukey 5\%. RIrefraction index; OR- optical rotation; SE- solubility in ethanol; V- viscosity; SG- specific gravity; ER- residue on evaporation; BP- boiling point.

\section{ACKNOWLEDGEMENTS}

Research support by the Universidade de Caxias do Sul and Secretaria de Estado da Ciência e Tecnologia (RGS) is acknowledged.

\section{RESUMO}

Dezenove amostras de Rosmarinus officinalis foram extraídas por destilação por arraste a vapor em uma planta piloto e os óleos essenciais foram avaliados quanto a composição química e características físico-químicas. Os rendimentos de óleo essencial variaram de $0,37 \%$ (média de 1999) a $0,49 \%$ (média de 1998). Vinte componentes foram identificados nos óleos essenciais. Os componentes majoritários foram $\alpha$-pineno $(40,55$ a $45,10 \%)$, 1,8-cineol $(17,40$ a $19,35 \%)$, canfeno $(4,73$ a $6,06 \%)$ e verbenona $(2,32$ a $3,86 \%)$. A média por safra dos parâmetros físico-químicos avaliados resultaram em $0,8887 \mathrm{~g} / \mathrm{cm}^{3}$ para densidade específica, 1,4689 para índice de refração e $+11,82^{\circ}$ para rotação óptica, sendo que 
as variações encontradas para os parâmetros químicos e físico-químicos dos óleos essenciais não variaram significativamente em função do ano de produção.

\section{REFERENCES}

Héthhelyi, E.; Kaposi, P.; Domonkos, J. and Kernóczi, Z. S. (1987), GC/MS investigation of the essential oils Rosmarinus officinalis L.. Acta Pharmaceutica Hungarica, 57, 159-169.

Svoboda, K. P. and Deans, S. G. (1992), A Study of the Variability of Rosemary and Sage and their Volatile Oils on the British Market: their Antioxidative Properties. Flavour and Fragrance Journal, 7, 81-87.

Guenther, E. (1972), The Essential Oils: Individual Essential Oils of the Plants Families Rutaceae and Labiatae. v. 3. Malabar, Florida, USA: Krieger Publishing Company.

Tewari, R. and Virmani, O. P. (1987), Chemistry of Rosemary Oil: A Review. Central Institute of Medicinal and Aromatic Plants, 9, 185-197.

Bauer, K.; Garbe, D. and Surburg, H. (1997), Common Fragrance and Flavor Materials. 3. ed. Germany: Wiley-VCH.

Tuker, A. O. and Maciarello, M. J. (1986), The essential oils of some rosemary cultivars. Flavour and Fragrance Journal, 1, 137-142.

Mizrahi, I.; Juarez, M. A. and Bandoni, A. L. (1991), The essential oil of Rosmarinus officinalis growiong in Argentina. Journal of Essential Oils Research, 3, 11-15.
Chalchat, J. C.; Garry, R. P.; Michet, A.; Benjilali, B. and Chabat, J. L. (1993), Essential oils of rosemary (Rosmarinus officinalis L.. The chemical composition of oils of various origins (Maroccom Spain, France). Journal of Essential Oils Research, 5, 613-618.

Lawrence, B. (1995), Progress in Essential Oils. Perfumer and Flavorist, 20, 47-54.

Rao, L. J.; Singh, M.; Raghavan, B. and, Abraham, K. O. (1997), Rosemary (Rosmarinus officinalis L.) Impact of drying on its flavor quality. Journal of Food Quality, 21, 107-115.

Dellacassa, E.; Lorenzo, D.; Moyna, P.; Frizzo, C.D.; Atti-Serafini, L. and Dugo, P. (1999), Rosmarinus officinalis L. (Labiatae) essential Oils from the South of Brazil and Uruguay. Journal of Essential Oils Research, 11, 27-30.

Price, S. and Price, L. (1999), Aromaterapy: for Health Proffecionals, 2. ed. London: Churchill Livingstone.

Received: July 09, 2004; Revised: December 01, 2004; Accepted: August 15, 2005 